\title{
Perbedaan Tingkat Agresivitas Petugas Satuan Polisi Pamong Praja di Bali ditinjau dari Dimensi Kepribadian Big Five dan Kecerdasan Emosional
}

\author{
Putu Tika Pratiwi dan Luh Kadek Pande Ary \\ Program Studi Psikologi, Fakultas Kedokteran, Universitas Udayana \\ tikapratiwi26@yahoo.co.id
}

\begin{abstract}
Abstrak
Agresivitas adalah setiap tindakan yang bertujuan untuk membahayakan atau melukai makhluk hidup lain,dimana agresivitas dapat dilakukan oleh siapa saja, dan tidak jarang justru dilakukan oleh aparat penegak hukum itu sendiri. Dalam berbagai pemberitaan diketahui bahwa anggota Satpol PP seringkali terlibat dalam tindakan agresivitas ketika menjalankan tugas. Adapun tujuan dari penelitian ini adalah untuk mengetahui perbedaan tingkat agresivitas petugas Satpol PP ditinjau dari dimensi kepribadian big five (neuroticsm, extraversion, openness to experience, agreeableness, conscientiousness) dan kecerdasan emosional.

Subjek penelitian ini adalah 135 anggota Satpol PP dari Kabupaten Badung yang dipilih dengan menggunakan teknik pengambilan sampel cluster sampling. Adapun instrumen dari penelitian ini adalah skala agresivitas, skala kepribadian big five, dan skala kecerdasan emosional. Pada penelitian ini untuk menganalisis data digunakan analisis kovarian (ancova). Hasil analisis kovarian menunjukkan bahwa dimensi kepribadian big five dan kecerdasan emosional memiliki kontribusi terhadap agresivitas anggota Satpol PP. Perbedaan agresivitas anggota Satpol PP berdasarkan dimensi kepribadian big five, secara signifikan menunjukkan bahwa ada perbedaan tingkat agresivitas ditinjau dari dimensi kepribadian big five yang dimiliki oleh masing-masing anggota Satpol PP. Sedangkan perbedaan tingkat agresivitas dilihat dari kecerdasan emosional sebagai kovarian dalam penelitian ini, menunjukkan bahwa secara signifikan ada perbedaan tingkat agresivitas ditinjau dari kecerdasan emosional.

Hasil penelitian juga menunjukkan bahwa kelompok subjek dengan dimensi kepribadian neuroticism memiliki rata-rata tingkat agresivitas yang lebih tinggi dibanding kelompok subjek lainnya. Diketahui pula bahwa kelompok subjek dengan rata-rata tingkat agresivitas yang paling rendah dimiliki oleh kelompok subjek dengan dimensi kepribadian openness to experience.
\end{abstract}

Kata Kunci : Agresivitas, Kepribadian Big five, Kecerdasan Emosional,Satpol PP.

\begin{abstract}
Aggressiveness is any action that aims to harm or injure other living beings, where aggressiveness can be done by anyone, and not infrequently it is done by the enforcers themselves. In various reports it is known that members of the Civil Service Police Unit are often involved in aggression while performing their duties. The purpose of this study was to determine differences in the aggressiveness of the Civil Service Police Unit officers in terms of the big five personality dimensions (neuroticsm, extraversion, openness to experience, agreeableness, conscientiousness) and emotional intelligence.

The subjects were 135 members of the Civil Service Police Unit of Badung selected using cluster sampling technique sampling. The instruments of this study are the scale of aggressiveness, the scale of the big five personality, and the scale of emotional intelligence. The study used analysis of covariance (ANCOVA) to analyze the data. The results of analysis of covariance showed that the big five personality dimensions and emotional intelligence contributes to the aggressiveness of the Civil Service Police Unit members. The different aggressiveness of members of the Civil Service Police Unit based on the big five personality dimensions significantly indicate that there is a difference of aggressiveness level in terms of the big five personality dimensions possessed by each member of the Civil Service Police Unit. While differences in the degree of aggressiveness seen from emotional intelligence as a covariance indicates that there is a significant difference in the level of aggressiveness in terms of emotional intelligence.

The findings also showed that the subject group with the personality dimension of neuroticism had a higher rate of aggressiveness than the other subjects. It is also known that the subject group with the lowest aggressiveness level was found on the subject group with personality dimension of openness to experience.
\end{abstract}

Keywords: Aggressiveness, Big Five Personality, Emotional Intelligence, Civil Service Police Unit 


\section{LATAR BELAKANG}

Manusia merupakan makhluk yang paling sempurna bila dibandingkan dengan makhluk lainnya, hal ini dikarenakan manusia diberi kelebihan berupa akal dan juga pikiran. Manusia juga merupakan makhluk sosial yang tidak dapat hidup sendiri serta membutuhkan sesamanya dalam kehidupan dan aktivitasnya. Sebagai makhluk sosial manusia senantiasa harus berhubungan dan bersosialisasi dengan manusia lainnya, baik untuk memenuhi kebutuhan fisik maupun psikologisnya (Firman, 2015). Interaksi antara manusia satu dengan manusia lainnya dapat terjadi di dalam suatu lingkungan baik lingkungan keluarga maupun masyarakat. Kegiatan bertemunya manusia dengan manusia yang lain akan menimbulkan berbagai kejadian dan pengalaman. Pengalaman tersebut dapat berupa kejadian yang menyenangkan ataupun tidak menyenangkan, salah satunya adalah pengalaman mengenai kekerasan.

Kekerasan merupakan salah satu bentuk perilaku yang dimiliki oleh setiap orang yang mengarah pada tindakan agresif. Baron dan Richardson (dalam Luthfi, Saloom, \& Yasun, 2009) menyebutkan bahwa agresivitas adalah setiap tindakan yang bertujuan untuk membahayakan atau melukai makhluk hidup lain serta terkait dengan adanya perasaan-perasaan marah atau permusuhan. Tindakan yang dimaksud disini baik dengan tindakan kekerasan secara fisik, verbal, maupun menggunakan ekspresi wajah dan gerakan tubuh yang mengancam atau merendahkan. Buss dan Perry (1992), membagi agresi kedalam empat bentuk yaitu agresi fisik, agresi verbal, agresi dalam bentuk sikap permusuhan dan yang terakhir adalah agresi dalam bentuk rasa marah. Keempat bentuk yang dikemukakan tersebut mewakili komponen motorik, afektif, dan kognitif dalam diri manusia. Tindakan kekerasan dapat terjadi baik di lingkungan keluarga, lingkungan sekolah, ataupun lingkungan masyarakat. Bahkan tidak jarang tindakan kekerasan justru dilakukan oleh aparat penegak hukum itu sendiri. Satuan Polisi Pamong Praja (Satpol PP) adalah salah satu dari sekian banyak aparat keamanan yang seringkali menjadi sorotan masyarakat, dan disebut terlibat dalam berbagai tindakan kekerasan serta pelanggaran HAM terkait dengan pelaksanaan tugasnya. Keterlibatan anggota Satpol PP dalam berbagai tindakan agresif dapat kita ketahui dari berbagai pemberitaan yang banyak membahas mengenai hal ini.

Satpol PP adalah perangkat pemerintah daerah dalam memelihara ketentraman dan ketertiban umum serta menegakkan peraturan daerah. Satpol PP memiliki tugas membantu kepala daerah untuk menciptakan kondisi daerah yang tentram, tertib, dan teratur sehingga penyelenggaraan roda pemerintahan dapat berjalan dengan lancar dan masyarakat dapat melakukan kegiatan dengan aman. Peraturan Pemerintah Nomor 32 Tahun 2004 menyebutkan bahwa petugas Satpol PP diwajibkan untuk tetap menjunjung tinggi norma hukum, norma agama, hak asasi manusia, serta norma sosial lainnya yang hidup dan berkembang dimasyarakat pada setiap pelaksanaan tugasnya (Rudhanto, 2010).

Tindakan agresif oleh individu menurut Koeswara (dalam Luthfi dkk, 2009) dapat dicetuskan oleh dua faktor utama yaitu faktor internal dan faktor eksternal. Faktor internal terdiri dari frustrasi, deindividuasi, stres, dan kepribadian sedangkan faktor eksternal terdiri dari kekuasaan dan kepatuhan, efek senjata, provokasi, alkohol dan obat-obatan, media massa, lingkungan fisik dan budaya. Oleh karena itu perilaku agresif yang dilakukan anggota Satpol PP di suatu daerah, tidak langsung dapat menggambarkan perilaku dari anggota Satpol PP di daerah lainnya. Satpol PP di Bali adalah salah satunya, dimana pemberitaan yang membahas mengenai berbagai perilaku agresif dari anggota Satpol PP di Bali sangat jarang sekali. Hal ini berbanding terbalik dengan beberapa pemberitaan mengenai perilaku-perilaku agresif yang dilakukan anggota Satpol PP di beberapa daerah lainnya. Kasus-kasus yang terkait dengan agresivitas yang melibatkan anggota Satpol PP juga terjadi di Bali, namun demikian jika dilihat dari berbagai pemberitaan yang ada, intensitas terjadinya tindakan agresif yang melibatkan anggota Satpol PP di Bali lebih sedikit dibandingkan daerah lain. Rudhanto (2010) menyebut bahwa ketidakpahaman petugas Satpol PP terhadap perintah untuk menindak tegas setiap pelanggaran yang terjadi, terkadang diartikan sebagai sebuah bentuk tindakan kekerasan atau perilaku agresif dalam mengatasi pelanggaran. Hal inilah yang kemudian membedakan satpol PP di satu daerah dengan daerah lainnya, dimana sesungguhnya perilaku agresif yang melibatkan anggota Satpol PP muncul akibat dari individu itu sendiri bukan institusinya.

Rendahnya keterlibatan anggota Satpol PP di Bali dalam kasus-kasus terkait dengan agresivitas, menunjukkan adanya perbedaan yang dimiliki individu dari anggota Satpol PP. Berbagai perilaku agresif yang ditunjukkan oleh anggota Satpol PP baik di Bali maupun di daerah lain, merupakan suatu bentuk respon individu terhadap suatu situasi yang dipengaruhi oleh berbagai hal. Perbedaan yang ditunjukkan oleh anggota Satpol PP satu dengan yang lainnya merupakan bentuk dari keunikan yang dimiliki oleh masing-masing individu. Setiap individu memiliki kognisi, afeksi, serta cara berperilaku yang berbeda ketika berada dalam situasi dan waktu yang berbeda (Burger, 2008). Perbedaan inilah yang membedakan masing-masing individu, sehingga antara individu satu dengan individu lainnya memiliki keunikannya sendiri. Keunikan dari setiap individu dimunculkan oleh berbagai hal, utamanya adalah dikarenakan oleh kepribadian individu itu sendiri. Kepribadian merupakan pola perilaku yang terdiri dari berbagai trait yaitu cara-cara dan kebiasaan berperilaku, berpikir, dan merasakan, yang memberikan karakter unik pada setiap individu (Carol \& Carol, 2007).

Definisi dari kepribadian yang diungkapkan oleh para ahli sangatlah beragam, hal ini dikarenakan tidak adanya satu teori tunggal yang mampu menjelaskan secara tepat dan akurat mengenai kepribadian. Salah satunya adalah definisi kepribadian dari Allport (dalam Suryabrata, 2008) yang mendefinisikan kepribadian sebagai organisasi dinamis dalam diri individu, sebagai sistem psikofisis yang akan menentukan cara khas individu, dalam menyesuaikan diri terhadap lingkungan. Kemudian menurut Feist dan Feist (2009), kepribadian merupakan pola watak dan karakter unik yang relatif permanen serta memiliki konsistensi dan keunikan pada perilaku individu. Salah satu teori kepribadian yang seringkali digunakan untuk menjelaskan kepribadian dari individu adalah 
menggunakan pendekatan kepribadian big five atau five factor model.

Big five adalah suatu pendekatan dalam psikologi yang digunakan untuk melihat kepribadian manusia melalui trait yang tersusun menjadi lima buah domain kepribadian yang dibentuk dengan menggunakan analisis faktor. Trait kepribadian adalah suatu dimensi dari perbedaan antar individu yang ditunjukkan dari pola pikir, perasaan, dan perbuatan yang konsisten Costa dan McRae (dalam Feist \& Feist, 2009). Konsep mengenai trait kepribadian ini telah banyak digunakan dalam berbagai penelitian hal ini dikarenakan trait dapat meringkas, memprediksi, dan menjelaskan tingkah laku seseorang. Sehingga kita dapat mengetahui bagaimana seseorang dapat berbeda dari orang lainnya dan kita juga dapat membuat prediksi mengenai bagaimana seseorang akan berperilaku selanjutnya. Dalam kepribadian big five kepribadian individu dibagi kedalam lima dimensi trait kepribadian yaitu neuroticism, extraversion, openness to new experience, agreeableness, dan conscientiousness, (Friedman \& Schustack, 2008).

Kelima dimensi kepribadian big five memiliki kecenderungan yang berbeda dalam mempengaruhi tingkat agresivitas. Individu dengan skor tinggi pada neuroticism cenderung penuh kecemasan, temperamental, emosional, dan rentan terhadap gangguan yang berhubungan dengan stres. Individu dengan skor tinggi pada extraversion cenderung penuh kasih sayang, ceria, senang berbicara, senang berkumpul, dan menyenangkan. Individu yang memiliki skor tinggi pada openness to new experience memiliki kecenderungan kreatif, imajinatif, penuh rasa penasaran, dan terbuka. Dimensi kepribadian agreeableness membedakan orang-orang yang berhati lembut dengan mereka yang kejam, dimana individu dengan skor agreeableness yang tinggi cenderung murah hati, pengalah, mudah menerima, dan memiliki perilaku yang baik. Dan yang terakhir dimensi kepribadian conscientiousness, dimana dimensi ini menggambarkan individu yang teratur, terkontrol, terorganisasi, ambisius, terfokus pada pencapaian, dan memiliki disiplin diri. Feist dan Feist (2009) mengatakan bahwa kecenderungan yang berbeda pada setiap dimensi akan membentuk sifat dari masing-masing kepribadian. Sifat-sifat kepribadian merupakan sebuah prediktor yang kuat untuk banyak aspek dalam kehidupan (Feist \& Feist, 2009). Sifat yang dimiliki oleh individu berdasarkan dimensi kepribadiannya, akan mendorong munculnya suatu pola perilaku tertentu pada individu termasuk perilaku agresif, sehingga individu akan bertindak sesuai dengan sifat yang dimilikinya.

Kepribadian bukan merupakan satu-satunya faktor yang mempengaruhi tingkat agresivitas dari individu. Sobur (2003) mengatakan bahwa berbagai perilaku agresif yang ditunjukkan oleh individu, merupakan bagian dari reaksi emosional. Perilaku agresif muncul dikarenakan adanya berbagai faktor yang pada akhirnya menekan emosi untuk bertindak agresif. Menurut Atkinson (1997) disebutkan bahwa agresi merupakan suatu reaksi emosional. Hal ini juga sejalan dengan pendapat dari Zillman (dalam Krahe 2005), yang menyatakan bahwa seseorang yang memiliki kerentanan secara emosional seringkali menunjukkan perilaku agresif yang lebih tinggi. Perilaku agresif juga merupakan barometer adanya suatu ketidakmampuan individu dalam mengatasi masalah yang dihadapi (Goleman, 2002). Bersumber dari berbagai pendapat yang telah disampaikan dapat diasumsikan bahwa emosi dan kemampuan individu dalam mengelola dan mengatur emosi dapat menjadi faktor pemicu timbulnya perilaku agresif. Emosi yang muncul pada diri individu terkait dengan tingkat kecerdasan emosional yang dimilikinya.

Kecerdasan emosional merupakan kemampuan untuk mengamati dengan tepat emosi diri sendiri dan orang lain, serta melatih dengan benar emosi diri sendiri (Goleman, 2002). Kecerdasan emosional juga merupakan suatu kemampuan untuk menjalankan emosi dan perilaku dalam berbagai situasi kehidupan serta menjalin hubungan baik secara tulus dengan keramahan dan rasa hormat. Bar-On (2006) menyatakan bahwa kecerdasan emosional merupakan suatu kemampuan dan kompetensi emosional serta sosial, yang mempengaruhi kemampuan individu untuk memahami dirinya dan orang lain, serta berhasil dalam mengatasi tekanan sehari-hari. Kecerdasan emosional merupakan akumulasi dari kecenderungan individu baik dari sifat bawaan maupun pengaruh dari faktor lingkungan.Individu yang cerdas secara emosional diharapakan dapat mengelola emosinya terutama ketika dihadapkan pada situasi yang kurang baik, sehingga dapat menekan munculnya perilaku agresif akibat dari reaksi emosional yang kurang terkontrol (Feist \& Feist, 2009). Hal ini didasarkan pada gambaran dari individu yang cerdas secara emosional yang memiliki kecenderungan untuk lebih optimis, fleksibel, lebih realistis, serta memiliki kemampuan untuk mengatasi masalah dan menghadapi berbagai tekanan (BarOn, 2006).

Kegagalan ataupun keberhasilan individu dalam mengelola kecerdasan emosional akan berpengaruh pada perilaku dan tindakan yang akan dimunculkan. Demikian pula dengan tipe kepribadian yang dimiliki masing-masing individu akan menentukan bagaimana respon individu terhadap suatu hal. Berdasarkan permasalahan serta fakta-fakta yang telah dipaparkan tersebut maka tujuan dari penelitian ini adalah untuk mengetahui perbedaantingkat agresivitas Petugas Satuan Polisi Pamong Praja di Bali ditinjau dari dimensi kepribadianbig five (neuroticsm, extraversion, openness to experience, agreeableness, conscientiousness) dan kecerdasan emosional.

\section{METODE PENELITIAN}

\section{Variabel Penelitian dan Definisi Operasional Variabel Penelitian}

Variabel adalah objek penelitian yang menjadi titik perhatian dalam suatu penelitian (Arikunto, 2002). Dalam penelitian ini terdapat tiga jenis variabel yaitu variabel tergantung (dependent variable) adalah agresivitas, kemudian variabel bebas (independent variable) pada adalah kepribadian big five, dan kovariabel atau disebut juga variabel kendali atau variabel kontrol adalah kecerdasan emosional. Adapun definisi operasional variabel penelitian adalah sebagai berikut :

Variabel Tergantung 
Agresivitas adalah kecenderungan individu untuk terlibat dalam tindakan agresi atau setiap perilaku yang dilakukan individu yang dimaksudkan untuk melukai atau mencelakakan, disertai pula adanya perasaan marah atau permusuhan, yang ditujukan pada orang lain baik dengan tindakan kekerasan secara fisik, verbal, maupun menggunakan ekspresi wajah, dan gerakan tubuh yang mengancam atau merendahkan.

Agresivitas diungkap dengan skala yang disusun sendiri oleh peneliti berdasarkan dimensi dari teori agresivitas dari Buss dan Perry (1992), yaitu agresi fisik, agresi verbal, agresi dalam bentuk sikap permusuhan dan yang terakhir adalah agresi dalam bentuk rasa marah.

Variabel Bebas

Definisi operasional kepribadian big five adalah suatu pendekatan dalam psikologi yang digunakan untuk melihat kepribadian manusia melalui trait kepribadian yaitu suatu dimensi yang akan membedakan individu satu dengan individu lain yang tergambarkan dari pola pikir, perasaan dan perbuatan yang konsisten. Kepribadian big five tersusun atas lima buah domain kepribadian, yaitu neuroticism, extraversion, openess to experience, agreeableness, conscientiousness.

Neuroticism, gambaran individu yang memiliki masalah dengan emosi negatif, menunjukkan kestabilan dan ketidakstabilan emosi individu serta mengidentifikasi kecenderungan mengalami stres, dan mempunyai ide-ide yang tidak realistis.

Extraversion, prediksi dari banyak tingkah laku sosial, penilaian kuantitas dan intensitas interaksi interpersonal, level aktivitas, kebutuhan untuk didukung, dan kemampuan untuk berbahagia, serta menunjukkan tingkat kesenangan individu akan hubungan.

Openess to experience, gambaran penilaian akan usaha individu secara proaktif dan penghargaannya terhadap pengalaman demi kepentingannya sendiri atau bagaimana individu bersedia menyesuaikan dirinya pada suatu ide ataupun pada situasi yang baru. Dimensi ini juga sangat berkaitan dengan keterbukaan wawasan dan orisinalitas ide.

Agreeableness, gambaran individu dengan kepribadian yang ramah, selalu mengalah, dan menghindari adanya konflik, orang yang kooperatif dan percaya pada orang lain.

Conscientiousness, gambaran kemampuan individu didalam organisasi, baik mengenai ketekunan dan motivasi dalam mencapai tujuannya, serta mencangkup perbedaan keteraturan dan disiplin diri dari setiap orang.

Kepribadian big five akan diukur dengan menggunakan skala yang mengacu pada International Personality Aitem Pool NEO (IPIP - NEO) yang dibuat oleh Lewis Goldberg pada tahun 1992, dengan adanya beberapa penambahan yang dilakukan oleh peneliti, yang menyesuaikan dengan kondisi dan lokasi dari subjek penelitian.

Kovariabel
Definisi operasional kecerdasan emosional adalah kemampuan individu dalam memahami, merasakan dan secara efektif mampu mengendalikan serta mengelola perasaan, menuntun pikiran dan tindakan juga kemampuan untuk memotivasi serta mengenali perasaan diri dan orang lain sehingga menjadikan individu pintar dalam mengelola emosinya dan mampu menciptakan keselarasan emosional luar dan dalam.

Kecerdasan emosional diungkap dengan skala yang disusun sendiri oleh peneliti berdasarkan dimensi dari teori kecerdasan emosional dari Goleman (2002). Dimensi tersebut terbagi dalam lima wilayah utama yaitu mengenali emosi diri, mengelola emosi, memotivasi diri sendiri, mengenali emosi orang lain, dan membina hubungan.

\section{Responden}

Populasi merupakan wilayah generalisasi yang terdiri dari objek ataupun subjek yang mempunyai kuantitas serta karakteristik tertentu yang telah ditetapkan oleh peneliti (Sugiyono, 2008). Maka dari itu populasi pada penelitian adalah anggota Satpol PP di Bali. Sampel merupakan sebuah bagian dari jumlah dan karakteristik yang dimiliki oleh populasi (Sugiyono (2008). Jadi subjek penelitian pada penelitian ini adalah anggota Satpol PP di Kabupaten dan Kota di Bali. Adapun karakteristik sampel yang akan diambil adalah (1) Anggota Satpol PP yang bertugas di lapangan (2) Masih aktif bertugas, (3) Bersedia menjadi subjek penelitian

Metode pengambilan sampel yang dilakukan dalam penelitian ini adalah probability sampling. Adapun teknik pengambilan sampel yang digunakan oleh peneliti adalah cluster sampling. Populasi dalam penelitian ini adalah seluruh anggota Satpol PP di Bali yang tersebar di seluruh Kabupaten dan Kota yang ada di Bali, yang mana keseluruhan populasi terbagi kedalam sembilan kluster. Penggunaan teknik sampling ini bertujuan untuk memilih anggota Satpol PP dari kabupaten mana yang nantinya akan menjadi sampel, dimana setelah dilakukan teknik sampling terpilihlah Kabupaten Badung. Jumlah sampel dalam penelitian ini sebanyak 135 orang anggota Satpol PP.

\section{Tempat Penelitian}

Untuk pengambilan data try out dilakukan pada anggota Satpol PP di Kabupaten Gianyar, sedangkan untuk pengambilan data setelah try out dilakukan pada anggota Satpol PP di Kabupaten Badung.

\section{Alat Ukur Penelitian}

Alat ukur pada penelitian ini menggunkan tiga buah skala yaitu skala agresivitas, skala kepribadian big five, dan skala kecerdasan emosional.

Skala Kepribadian Big five

Dalam penelitian ini variabel kepribadian big five akan diukur dengan menggunakan skala yang mengacu pada International Personality Aitem Pool NEO (IPIP - NEO) yang dibuat oleh Lewis Goldberg pada tahun 1992. Skala ini diterjemahkan oleh Adriaan H. Boon Van Ostade bernama 100 Big Five factor markies. Skala ini dibuat berdasarkan teori big five yang digunakan oleh Costa \& Mc Crae dalam membuat NEO PI-R. Adapun skala yang diadaptasi dari IPIP - NEO yang digunakan untuk mengukur variabel kepribadian big five 
dalam penelitian ini, terdiri atas 50 aitem pernyataan. Masingmasing aitem terdiri atas 10 pernyataan yang memiliki rentang nilai dari sangat sesuai sampai dengan sangat tidak sesuai. Jenis data yang diperoleh adalah data interval. Sebelum alat ukur digunakan untuk pengambilan data penelitian, terlebih dahulu dilakukan uji coba terhadap kuisioner. Uji coba yang dilakukan pada 60 orang anggota Satpol PP Kabupaten Gianyar, menyatakan bahwa validitas kuisioner kepribadian big five bergerak dari -0,328 - 0,679. Reliabilitas kuisioner kepribadian big five adalah sebesar 0,909 yang berada diatas nilai maksimum 0,6 maka dapat disimpulkan bahwa skala reliabel (Azwar, 2008).

Skala Kecerdasan Emosional

Variabel kecerdasan emosional diukur dengan menggunakan skala kecerdasan emosional dimana alat ukur ini disusun berdasarkan aspek-aspek kecerdasan emosional dari Goleman, (2002). Adapun jumlah aitem pada skala kecerdasan emosional adalah sebanyak 40 pernyataan. Uji coba terhadap kuisioner kecerdasan emosional, menyatakan bahwa validitas kuisioner kecerdasan emosional bergerak dari 0,008 - 0,693. Reliabilitas kuisioner kecerdasan emosional adalah sebesar 0,899 yang berada diatas nilai maksimum 0,6 maka dapat disimpulkan bahwa skala reliabel (Azwar, 2008).

$\underline{\text { Skala Agresivitas }}$

Variabel agresivitas diukur dengan menggunakan skala agresivitas yang disusun berdasarkan konsep Buss dan Perry (1992), yang menyatakan bahwa terdapat 4 bentuk agresi yaitu, agresi fisik, agresi verbal, sikap permusuhan dan rasa marah. Skala agresivitas dalam penelitian ini, terdiri atas 40 aitem pernyataan. Uji coba terhadap kuisioner agresivitas, menyatakan bahwa validitas kuisioner kecerdasan emosional bergerak dari rentang $-0,027-0,695$. Reliabilitas kuisioner kecerdasan emosional adalah sebesar 0,885 yang berada diatas nilai maksimum 0,6 maka dapat disimpulkan bahwa skala reliabel (Azwar, 2008).

\section{Teknik Pengumpulan Data}

Penelitian ini menggunakan kuisioner sebagai alat untuk mengumpulkan data serta informasi dari responden secara langsung. Dalam penelitian ini terdapat tiga kuisioner yang digunakan oleh peneliti untuk mengumpulkan data, yang pertama adalah kuisioner kepribadian big five, yang kedua kuisioner kecerdasan emosional, dan yang ketiga kuisioner agresivitas. Dalam kuisioner ini peneliti menggunakan jenis pertanyaan tertutup yaitu bentuk pertanyaan dimana subyek hanya memilih jawaban yang telah tersedia dalam kuisioner. Untuk mengetahui sejauh mana respon dari subjek penelitian terhadap suatu pernyataan, maka disediakan empat pilihan jawaban yakni SS (Sangat Sesuai), S (Sesuai), TS (Tidak Sesuai), STS (Sangat Tidak Sesuai). Proses pengumpulan data pada penelitian ini dilakukan mulai dari akhir bulan September 2014 sampai dengan bulan Desember 2014, yang dilakukan pada anggota Satpol PP Kabupaten Badung. Data yang terkumpul, kemudian dilakukan skoring oleh peneliti untuk kemudian dilakukan analisis data.

\section{Teknik Analisis Data}

Pada penelitian ini analisis data yang digunakan adalah analisis statistik inferensial yaitu teknik statistik yang digunakan untuk menganalisis data sampel dan hasilnya diberlakukan dalam sebuah populasi (Sugiyono, 2008). Analisis data dilakukan dengan bantuan program analisis statistik komputer yaitu Statistical Package for Social Science (SPSS) versi 17.00. Sesuai dengan tujuan dari penelitian ini yaitu untuk untuk mengetahui perbedaan tingkat agresivitas petugas Satuan Polisi Pamong Praja ditinjau dari dimensi kepribadian big five (neuroticsm, extraversion, openness to experience, agreeableness, conscientiousness) dan kecerdasan emosional, maka teknik analisis yang digunakan peneliti adalah Analysis of Covariance (ANCOVA). Analysis of Covariance (ANCOVA) dalam penelitian ini bertujuan untuk melihat perbedaan variabel tergantung ditinjau dari variabel bebas dengan adanya kontrol terhadap variabel bebas lainnya atau kovariat.

\section{HASIL PENELITIAN}

Sebelum melakukan Analysis of Covariance (ANCOVA), peneliti terlebih dahulu harus memenuhi dan melakukan pengujian asumsi terhadap data penelitian, yaitu melakukan uji normalitas, uji homogenitas, dan uji linearitas.

\section{Uji Normalitas}

Uji normalitas dalam penelitian ini diuji dengan menggunakan Kolmogorov-Smirnov pada program SPSS 17.0 for windows. Uji normalitas bertujuan untuk mengetahui apakah sebaran data antara variabel agresivitas, kecerdasan emosional dan kepribadian big five bersifat normal atau tidak. Data dikatakan memiliki distribusi yang normal apabila signifikansi lebih besar dari 0,05 ( $>00,05)$ (Azwar, 2008). Berikut adalah hasil pengujian normalitas yang dapat dilihat pada tabel berikut. (Tabel 1. Hasil Uji Normalitas Data Agresivitas dan Kecerdasan Emosional-. Terlampir).

Sebaran data variabel agresivitas memiliki nilai signifikansi dengan probabilitas sebesar $0.133(\mathrm{p}>0,05)$ sehingga sebaran data pada variabel agresivitas berdistribusi normal. Sebaran data pada variabel kecerdasan emosional memiliki nilai signifikansi dengan probabilitas sebesar $0.152 \quad(\mathrm{p}>0,05)$ sehingga sebaran data pada variabel kecerdasan emosional berdistribusi normal.

\section{Uji Homogenitas}

Pada penelitian ini uji homogenitas dilakukan dengan bantuan SPSS dengan menggunakan Levene's Test of Homogenity of Variances. Tingkat signifikansi yang lebih besar dari 0,05 ( $p>0,05)$ menunjukkan bahwa data penelitian tersebut bersifat homogen. Adapun hasil dari pengujian tercantum pada tabel berikut. (Tabel 2. Hasil Uji Homogenitas. Terlampir).

Pada tabel diketahui bahwa variabel agresivitas memiliki nilai Levene Statistic sebesar 1.246 dan nilai signifikansi (p) sebesar 0.295 . Nilai signifikansi yang lebih besar dari 0,05 $(\mathrm{p}>0,05)$ dapat disimpulkan bahwa varian dalam data agresivitas adalah sama atau homogen. Pada tabel juga terlihat bahwa nilai Levene Statistic variabel kecerdasan emosional sebesar 1.578 dan nilai signifikansi (p) sebesar 0.184. Nilai signifikansi yang lebih besar dari $0,05 \quad(p>0,05)$ dapat disimpulkan bahwa varian dalam data kecerdasan emosional adalah sama atau homogen. 


\section{Uji Linearitas}

Uji linearitas bertujuan untuk mengetahui apakah dua variabel mempunyai hubungan yang linier atau tidak secara signifikan. Dalam penelitian ini pengujian dilakukan dengan bantuan SPSS dengan menggunakan Test for Linearity Compare Means pada taraf signifikan 5\%. Apabila signifikansi ( linearity ) kurang dari $0,05(\mathrm{p}<0,05)$ maka dapat dikatakan linier. Sedangkan apabila signifikansi ( linearity) lebih dari $0,05$ ( $p>0,05)$ maka dapat dikatakan tidak linier. Adapun hasil pengujian dapat dilihat pada tabel berikut. (Tabel 3. Hasil Uji Linearitas-. Terlampir).

Pada tabel diketahui bahwa hasil uji linearitas variabel agresivitas dan kecerdasan emosional pada n sampel sebanyak 135 menunjukkan nila $\mathrm{F}=88.621$ dengan nilai signifikansi pada linearity sebesar 0.000 . Karena signifikansi kurang dari $0,05(\mathrm{p}<0,05)$, maka dapat disimpulkan bahwa antara variabel agresivitas dan kecerdasan emosional terdapat hubungan yang linier.

Peneliti membedakan kategori dari masing-masing variabel dengan menggunakan rumus rentangan berdasarkan standar deviasi dan mean empiris dilihat dari kurva normal (Azwar, 1997). Kategorisasi yang dilakukan oleh peneliti terbagi kedalam 5 kategori, yaitu kategori sangat rendah, rendah, sedang, tinggi, dan sangat tinggi.

\section{Kategorisasi Variabel Agresivitas}

Berdasarkan rumus pengkategorian skor, peneliti kemudian mengkategorikan variabel agresivitas ke dalam lima kategori. Pengkategorian skor variabel agresivitas beserta frekuensi dan persentasenya akan dicantumkan dalam tabel berikut. (Tabel 4. Kategorisasi Skor Agresivitas. Terlampir).

Berdasarkan kategorisasi yang telah dilakukan, dapat diketahui bahwa persentase paling besar terdapat pada kategori skor rendah, artinya sebanyak $80 \%$ subjek penelitian berada pada kategori ini. Sedangkan persentase paling kecil terdapat pada kategori tinggi dan sangat tinggi yaitu $0 \%$ artinya tidak ada subjek yang berada pada kategori ini.

\section{Kategorisasi Variabel Kecerdasan Emosional}

Berdasarkan rumus pengkategorian skor, peneliti kemudian mengkategorikan variabel kecerdasan emosional ke dalam lima kategori. Pengkategorian skor variabel kecerdasan emosional beserta frekuensi dan persentasenya tercantum dalam tabel 5 berikut. (Tabel 5. Kategorisasi Skor Kecerdasan emosional. Terlampir).

Berdasarkan kategorisasi pada tabel, dapat diketahui bahwa persentase subjek penelitian pada variabel kecerdasan emosional yang paling besar, terdapat pada kategori skor tinggi yaitu sebesar $73.3 \%$ subjek penelitian berada pada kategori ini. Sedangkan persentase paling kecil terdapat pada kategori sangat rendah dan kategori rendah yaitu $0 \%$ artinya tidak ada subjek yang berada pada kategori ini.

\section{Kategorisasi Variabel Kepribadian Big five}

Tujuan kategorisasi pada variabel big five adalah untuk menempatkan individu ke dalam kelompok-kelompok diagnosis yang tidak memiliki makna lebih dan kurang atau tinggi dan rendah. Hal ini dikarenakan kategori yang dikehendaki adalah kategori nominal, sehingga tidak terletak dalam suatu kontinum. Selain itu kelima dimensi dari variabel kepribadian big five masing-masing memiliki jumlah aitem yang berbeda-beda, maka untuk mengkategorikannya perlu dilakukan perhitungan standar baku ( z skor ).

Pada penelitian ini perhitungan standar baku ( $\mathrm{Z}$ skor ) dianalisis dengan bantuan program Statistical Package for Social Science (SPSS). Setelah semua skor mentah dari masing-masing dimensi distandar bakukan, kemudian masingmasing skor ( $\mathrm{z}$ skor) dibandingkan dimana peneliti terlebih dahulu harus menetapkan harga $\mathrm{z}$ minimal (Azwar, 2008). Pada penelitian ini peneliti menetapkan harga $\mathrm{z}$ minimal sebesar 1,25 hal ini dikarenakan variabel kepribadian big five digunakan untuk membedakan individu kedalam 5 kelompok dimensi. Berikut kriteria kategorisasi dimensi kepribadian big five. (Tabel 6. Kriteria Kategorisasi Kepribadian Big Five. Terlampir).

Berdasarkan kriteria kategorisasi yang telah ditetapkan, berikut adalah tabel yang memuat hasil kategori masingmasing dimensi kepribadian

(Tabel 7. Kategorisasi Kepribadian Big Five. Terlampir). Berdasarkan tabel dapat diketahui bahwa persentase jumlah subjek pada masing-masing dimensi kepribadian big five dalah sebesar $20 \%$, dimana jumlah subjek pada setiap dimensi kepribadian big five adalah sebanyak 27 orang.

Analysis of Covariance (ANCOVA) bertujuan untuk melihat perbedaan antara variabel tergantung yang ditinjau dari variabel bebas dengan adanya kontrol terhadap variabel bebas lainnya (kovariat). Berikut adalah hasil uji Analysis of Covariance (ANCOVA). (Tabel 8. Perhitungan Statistik Ancova-. Terlampir).

Pada tabel terlihat bahwa signifikansi homogenitas setelah adanya kontrol terhadap variabel kecerdasan emosional tetap menunjukkan signifikansi yang lebih besar dari 0.05 yaitu sebesar $0.368 \quad(p>0.05)$ sehingga dapat disimpulkan bahwa varian data memang homogen.

(Tabel 9. Perhitungan Statistik Ancova. Terlampir). Pada tabel 9 terlihat bahwanilai signifikansi pada bagian Corrected Model sebesar 0.000 , dimana nilai tersebut berada dibawah $0.05(\mathrm{p}<0.05)$, sehingga dapat disimpulkan bahwa Ho ditolak. Hal ini menunjukkan bahwa pada tingkat kepercayaan $95 \%$ kecerdasan emosional dan kepribadian big five memiliki kontribusi terhadap tingkat agresivitas pada petugas Satpol PP. Pada tabel 10 nilai Adjusted $R$ Squared adalah sebesar 0.365 yang berarti bahwa variabel tingkat agresivitas yang dapat dijelaskan oleh dimensi kepribadian big five dan kecerdasan emosional adalah sebesar $36,5 \%$.

Nilai Adjusted $R$ Squared mengalami peningkatan dari sebelum dilakukan kontrol terhadap variabel kecerdasan 
emosional. Dimana sebelum dilakukan kontrol terhadap variabel kecerdasan emosional nilai Adjusted $R$ Squared agresivitas ditinjau dari kepribadian big five adalah sebesar 0.185 . Hal ini memiliki arti bahwa variabel agresivitas hanya dapat dijelaskan oleh dimensi kepribadian big five sebesar 18.5\%. Adanya kenaikan nilai Adjusted $R$ Squared setelah dilakukan kontrol terhadap variabel kecerdasan emosional, menandakan bahwa model menjadi lebih baik. Berikut adalah tabel perhitungan statistik ANOVA tanpa adanya kotrol terhadap variabel kecerdasan emosional yang tercantum pada tabel 10. (Tabel 10. Perhitungan Statistik Anova-. Terlampir).

(Tabel 11. Mean, Standar Deviasi Kelompok Dimensi Kepribadian Big Five-. Terlampir). Tabel 11 menunjukkan bahwa jumlah (n) sampel disetiap kelompok adalah sama yaitu 27 orang. Pada kelompok subjek yang masuk dalam dimensi kepribadian neuroticism memiliki mean kelompok sebesar 72.59. Pada kelompok subjek yang masuk dalam dimensi kepribadian extraversion memiliki mean kelompok sebesar 65.33. Pada kelompok subjek yang masuk dalam dimensi kepribadian openness memiliki mean kelompok sebesar 63.52. Pada kelompok subjek yang masuk dalam dimensi kepribadian agreeableness memiliki mean kelompok sebesar 65.78. Pada kelompok subjek yang masuk dalam dimensi kepribadian conscientiousness memiliki mean kelompok sebesar 64.89 .

(Tabel 12. Estimated Marginal Means Dimensi Kepribadian Big Five-. Terlampir). Tabel 12 menunjukkan nilai rata-rata dari setiap kelompok setelah adanya kontrol terhadap variabel kecerdasan emosional sebagai kovariat. Pada tabel diatas juga ditunjukkan bahwa telah terjadi penurunan dan peningkatan nilai rata-rata disetiap kelompok, namun tidak terlalu signifikan. Terjadinya penurunan dan peningkatan nilai ratarata disetiap kelompok menunjukkan bahwa nilai rata-rata pada setiap kelompok telah mengalami penyesuaian dengan nilai dari variabel kecerdasan emosional yang dikontrol sebagai kovariat. Berdasarkan hasil uji hipotesis dapat diketahui bahwa hipotesis yang diterima pada penelitian adalah seperti yang tercantun pada tabel 13. (Tabel 13. Rangkuman Hasil Uji Hipotesis Penelitian. Terlampir).

\section{PEMBAHASAN DAN KESIMPULAN}

Berdasarkan analisis data yang telah dilakukan dengan Analysis of Covariance (ANCOVA), dimana pada bagian Corrected Model menunjukkan nilai F test sebesar 16.401 dengan nilai signifikansi sebesar 0.000 nilai tersebut berada dibawah $0.05(\mathrm{p}<0.05)$. Oleh karena itu dapat disimpulkan bahwa dimensi kepribadian big five (neuroticsm, extraversion, openness to experience, agreeableness, dan conscientiousness) dan kecerdasan emosional memiliki kontribusi dengan tingkat agresivitas pada petugas Satpol PP. Kontribusi dari dimensi kepribadian big five dan kecerdasan emosional terhadap agresivitas, seperti yang tercantum pada tabel, menunjukkan angka sebesar $36,5 \%$. Artinya terdapat kontribusi variabel lain sebesar $63,5 \%$ yang dapat mempengaruhi tingkat agresivitas individu.

Ditinjau dari dimensi kepribadian big five, perbedaan tingkat agresivitas pada petugas Satpol PP secara signifikan menunjukkan angka uji beda $\mathrm{F}=3.652$ dengan signifikansi sebesar 0.007 dimana nilai tersebut berada dibawah 0.05 $(\mathrm{p}<0.05)$. Hal ini berarti bahwa ada perbedaan tingkat agresivitas pada petugas Satpol PP berdasarkan dimensi kepribadian big five (neuroticsm, extraversion, openness to experience, agreeableness, dan conscientiousness). Hal ini sesuai dengan apa yang disampaikan Baron dan Byrne (2005), dimana tipe kepribadian merupakan salah satu hal yang dapat mempengaruhi individu untuk berperilaku agresif. Kepribadian juga dapat mempengaruhi aktivasi konsep-konsep yang berhubungan dengan agresi didalam memori dan memberi pengaruh terhadap cognition, affect, arousal yang pada akhirnya mempengaruhi tingkah laku (Anderson \& Bushman, 2002).

Hal ini sejalan dengan pendapat Koeswara 1998 (dalam Luthfi dkk, 2009), bahwa munculnya perilaku agresivitas dipengaruhi oleh berbagai faktor. Salah satunya adalah kepribadian, melalui kepribadian yang dimiliki oleh individu dapat diprediksi perilaku serta respon yang akan dimunculkan oleh individu ketika menghadapi suatu situasi. Hal ini dikarenakan kepribadian merupakan suatu pola yang tersusun atas banyak trait, yaitu cara-cara dan kebiasaan berperilaku, berpikir, dan merasakan yang akan memberi karakter pada individu sepanjang waktu dan pada berbagai situasi (dalam Carol \& Carol, 2007). Perbedaan kognisi, afeksi, serta cara berperilaku dari setiap individu ketika berada pada suatu waktu dan situasi, merupakan suatu kekhasan yang muncul karena pengaruh dari tipe kepribadian yang dimiliki. Dalam penelitian ini tipe kepribadian yang dimaksud adalah big five.

Setelah ditelusuri secara lebih mendalam, terkait dengan kelompok subjek mana yang memiliki tingkat agresivitas yang lebih tinggi, jika dilihat dari mean kelompok pada tabel 12 menunjukkan secara statistik, kelompok yang masuk dalam dimensi kepribadian neuroticism memiliki rata-rata tingkat agresivitas yang lebih tinggi dibandingkan kelompok subjek lainnya. Dimensi kepribadian neuroticsm menurut Costa dan McCrae (dalam Pervin, 2005) terkait dengan kestabilan dan ketidakstabilan emosi yang dimiliki oleh individu.Feist dan Feist (2009) juga menyatakan bahwa seseorang dengan skor neuroticsm yang tinggi, lebih mudah mengalami emosi negatif seperti perasaan marah, cemas, depresi serta sering kali mengalami ketidakstabilan emosi. Pada penelitian ini sebanyak $20 \%$ subjek penelitian atau sebanyak 27 orang masuk dalam dimensi kepribadian neuroticsm.

Individu dengan skor neuroticsm yang tinggi memiliki kecenderungan untuk mudah merasa cemas, gugup, emosional, merasa tidak aman, merasa tidak mampu, dan mudah panik serta rentan terhadap gangguan stres (Costa \& McRae dalam Pervin, 2005). Hal ini tidak lepas dari gambaran individu dengan skor neuroticsm tinggi, yang mudah mengalami gangguan stres dan emosional, sehingga situasi biasa dapat terlihat sebagai sebuah ancaman. Hal inilah yang dapat memicu mereka untuk bertindakan agresif kepada orang lain yang dianggap dapat mengganggu keamanan dan kenyamanan mereka. Hal ini juga sejalan dengan penelitian yang dilakukan Al-jum'atu Rahmatillah, (2011) yang menunjukkan bahwa dimensi neuroticsm dalam kepribadian 
big five berkolerasi positif dengan agresivitas.

Dimensi yang kedua adalah extraversion, dimana pada penelitian ini sebanyak 27 orang atau sebesar 20\% subjek penelitian masuk dalam dimensi ini. Berdasarkan tabel 13 diketahui bahwa secara statistik kelompok yang masuk dalam dimensi kepribadian extraversion, jika diurutkan memiliki rata-rata tingkat agresivitas diurutan ketiga setelah neuroticsm dan conscientiousness. Dari hasil penelitian diketahui pula bahwa subjek penelitian yang masuk dalam dimensi kepribadian extraversion paling banyak memiliki tingkat agresivitas rendah. Hal ini sejalan dengan penelitian yang dilakukan oleh Mastur (2012) yang menunjukkan bahwa tipe kepribadian yang cenderung dimiliki oleh petarung peresean adalah extraversion dengan tingkat agresivitas sedang.

Tinngkat agresivitas yang rendah pada kelompok subjek yang masuk dalam dimensi kepribadian extraversion tidak bisa dilepaskan dari gambaran karakteristik yang dimiliki oleh individu dengan skor tinggi pada dimensi ini. Menurut Costa dan McCrae (dalam Pervin, 2005), individu dengan kepribadian extraversion dikatakan mudah menyesuaikan diri dengan lingkungan sosial, aktif, banyak bicara, berorientasi pada hubungan dengan sesama, optimis, penuh kasih sayang, dan terbuka dengan perasaannya. Individu yang memiliki kepribadian extraversion juga digambarkan memiliki kecenderungan untuk bersifat tegas ketika mengambil suatu keputusan serta tidak ragu untuk memposisikan diri sebagai pemimpin (Ghufron \&Risnawati, 2010).

Satpol PP dalam menjalankan tugas dan tanggung jawabnya akan senantiasa berinteraksi serta bersinggungan dengan kepentingan masyarakat. Dalam situasi serta kondisi yang seringkali tidak kondusif, individu yang memiliki kepribadian extraversion akan lebih mampu mengekspresikan sikap tegasnya dengan baik dan bijaksana, dengan tetap mengedepankan komunikasi yang baik, sikap ramah, penuh kasih sayang, dan menunjukkan keakraban yang lebih. Hal ini dikarenakan mereka yang memiliki kepribadian extraversion memiliki orientasi tinggi terhadap hubungan dengan sesama, sehingga potensi untuk memunculkan tindakan yang dapat menyakiti atau melukai orang lain akan lebih kecil.

Dimensi yang ketiga adalah openness to experience, dimana pada penelitian ini subjek penelitian yang masuk dalam dimensi kepribadian openness to experience berjumlah 27 orang atau sebesar 20\%. Berdasarkan tabel 12 diketahui bahwa secara statistik kelompok yang masuk dalam dimensi kepribadian openness to experience merupakan kelompok subjek dengan rata-rata tingkat agresivitas yang paling rendah. Kemudian dilihat dari ketegorisasi tingkat agresivitas yang dimiliki oleh anggota Satpol PP yang masuk dalam dimensi ini, kebanyakan berada pada kategorisasi rendah. Hal ini sesuai dengan teori Costa dan McRae (dalam Pervin, 2005) dimana individu dengan skor tinggi pada openness to experience, memiliki rasa ingin tahu yang tinggi, minat yang luas, berani mencoba hal-hal baru, berpikiran terbuka, kreatif, orisinil, imajinatif, dan modern. Anggota Satpol PP dengan kepribadian openness to experience yang berpikiran terbuka dan memiliki pandangan yang luas, akan mampu bersikap terbuka untuk mencari solusi pada masalah ataupun hal-hal yang dapat mengganggu tercapainya tujuan mereka. Keterbukaan sikap maupun pikiran yang dimiliki akan sangat membantu anggota Satpol PP untuk melakukan penyesuai diri terhadap berbagai hal yang terjadi ketika melaksanakan tugas, serta akan membantu anggota Satpol PP untuk dapat melihat suatu masalah dari perspektif orang lain.

Dimensi yang keempat adalah agreeableness, dimana individu dengan skor tinggi pada dimensi agreeableness digambarkan memiliki karakteristik seperti memiliki hati yang lembut, baik hati, dapat dipercaya, suka menolong, pemaaf, penurut dan jujur (Costa \& McRae dalam Pervin, 2005). Pada penelitian ini sebanyak 27 orang subjek penelitian atau sebesar $20 \%$ masuk dalam dimensi kepribadian agreeableness dan sebagian besar memiliki tingkat agresivitas yang rendah. Sedangkan berdasarkan tabel 12 diketahui bahwa secara statistik kelompok yang masuk dalam dimensi kepribadian agreeableness, jika diurutkan memiliki rata-rata tingkat agresivitas diurutan keempat setelah neuroticsm, conscientiousness, dan extraversion. Hasil dari penelitian ini sejalan dengan penelitian dari Denson, Pedersen, \& Miller (2006) yang menunjukkan bahwa dimensi kepribadian agreeableness dalam kepribadian big five berpengaruh signifikan terhadap agresivitas.

Kepribadian agreeableness diasosiasikan sebagai kepribadian yang berfokus pada perilaku prososial pada orang lain, menghindari konflik, serta altruism yaitu sifat murah hati, memiliki keinginan untuk membantu orang lain, serta selalu mendahulukan kepentingan orang lain (Costa \& McRae, 1992; John, 1990). Sedangkan agresivitas sendiri menurut Berkowitz (dalam Luthfi dkk, 2009) adalah segala bentuk perilaku yang diusahakan untuk menyakiti orang lain baik secara fisik maupun secara psikologis. Oleh karena itu karakteristik dari individu dengan skor agreeableness tinggi sangat bertolak belakang dengan perilaku agresivitas. Hal ini juga sejalan dengan teori yang dikemukan oleh Timothy (dalam Ghufron \& Risnawati 2010), dimana individu dengan skor tinggi pada dimensi agreeableness identik dengan seseorang yang berprilaku prososial. Maka dari itu dalam menjalankan tugas dan tanggung jawab untuk menindak setiap pelanggaran dengan tegas tanpa terkecuali, mereka akan mengedepankan pendekatan yang baik dibandingkan tindakan-tindakan agresif.

Dimensi yang kelima adalah conscientiousness, dimana pada penelitian ini sebanyak 27 orang subjek penelitian masuk kedalam dimensi kepribadian conscientiousness. Lebih lanjut pada penelitian ini juga diketahui bahwa tingkat agresivitas yang dimiliki oleh kelompok subjek penelitian dengan kepribadian conscientiousness kebanyakan berada pada kategori rendah. Hal ini sejalan dengan hasil penelitian yang dilakukan oleh Rahmatillah, (2011), dan juga hasil penelitian dari Fauziah (2014) dimana dimensi conscientiousness dalam kepribadian big five berkorelasi negatif dengan agresivitas. Hasil penelitian ini juga didukung oleh penelitian dari Denson dkk (2006) yang menunjukkan bahwa dimensi kepribadian conscientiousness berpengaruh signifikan terhadap agresivitas.

Namun demikian berdasarkan tabel 13 diketahui bahwa secara 
statistik kelompok yang masuk dalam dimensi kepribadian conscientiousness, memiliki rata-rata tingkat agresivitas diurutan kedua tertinggi setelah neuroticsm. Hal ini tidak bisa dilepaskan dari karakteristik individu yang memiliki skor tinggi pada dimensi conscientiousness. Adapun individu yang berkepribadian conscientiousness digambarkan sebagai pribadi yang teratur, pekerja keras, dapat diandalkan, disiplin, tepat waktu, rapi, mempertimbangkan segala sesuatu sebelum dilakukan, mengikuti norma dan aturan serta selalu memprioritaskan tugas (Costa \& McRae, 1992; John, 1990).

Sebagaimana individu dengan pribadi yang teratur, disiplin, dan tepat waktu, ketika dihadapkan pada situasi yang tidak mereka inginkan, memiliki kemungkinan yang lebih besar untuk melakukan berbagai upaya termasuk bertindak agresif demi tercapainya tujuan mereka. Akan tetapi individu dengan kepribadian conscientiousness, juga digambarkan sebagai pribadi yang mampu menimbang baik dan buruk setiap hal yang akan mereka lakukan. Sehingga setiap tugas dan tanggung jawab yang mereka lakukan dalam kondisi apa pun akan tetap dijalankan berdasarkan norma dan aturan yang ada.

Masing-masing kepribadian yang dimiliki oleh setiap individu memiliki kecenderungan yang berbeda untuk bertindak agresif. Hal ini dipengaruhi oleh karakteristik yang dimiliki oleh setiap dimensi kepribadian. Namun demikian kepribadian bukan satu-satunya faktor yang dapat menentukan tinggi rendahnya tingkat agresivitas yang dimiliki oleh anggota Satpol PP. Hal ini dapat kita lihat dari hasil penelitian yang menunjukkan bahwa kepribadian hanya berkontribusi sebesar $18.5 \%$ terhadap tingkat agresivitas.

Interaksi antara kecerdasan emosional sebagai covarian dengan tingkat agresivitas menunjukkan angka uji beda $\mathrm{F}=$ 37.799 dengan signifikansi sebesar 0.000 dimana nilai tersebut berada dibawah $0.05(\mathrm{p}<0.05)$. Hal ini menandakan bahwa ada perbedaan tingakat agresivitas pada petugas Satpol PP berdasarkan kecerdasan emosional. Kecerdasan emosional adalah kemampuan untuk dapat memotivasi diri, mengenali perasaan diri sendiri dan perasaan orang lain, kemampuan pengendalian diri, kemampuan mengelola emosi dengan baik pada diri sendiri, dan dalam hubungan dengan orang lain serta kemampuan mengendalikan dorongan hati (Goleman (2002). Kecerdasan emosional merujuk pada suatu kemampuan untuk mengendalikan dan mengelola berbagai dorongan emosi yang ada pada diri individu.

Sejalan dengan hasil dari penelitian ini, menurut Salovey dan Mayer (dalam Goleman, 2002) kecerdasan emosional merupakan suatu kemampuan individu untuk mengamati dan mengendalikan perasaan serta emosinya dan orang lain, untuk kemudian dijadikan panduan bagi individu dalam mengendalikan pikiran dan tindakannya. Anggota Satpol PP dengan kecerdasan emosional yang baik, akan dapat mengotrol dirinya untuk tidak melakukan berbagai tindakan kekerasan yang dapat merugikan baik bagi dirinya maupun orang lain. Hal ini sesuai dengan pendapat dari Yusof dan Yacob (2012) dimana kecerdasan emosional dipandang sebagai cermin untuk merefleksikan kemampuan individu dalam bernegosiasi dengan orang lain secara baik serta untuk mengotrol diri, kecerdasan emosional juga terkait dengan kemampuan untuk mengatasi tantangan yang ada di lingkungan. Pandangan yang terkait dengan kecerdasan emosional ini memberikan gambaran mengenai bagaimana emosi mempengaruhi individu dalam bertindak untuk menyesuaikan diri dengan lingkungan dan berbagai kondisi yang ada didalamnya.

Moskat dan Sorensen (2012) menyebutkan bahwa apabila individu memiliki kecerdasan emosional yang tinggi maka individu akan lebih mampu untuk menyesuaikan diri dengan berbagai norma yang ada sebelumnya, sehingga mengurangi kecenderungan untuk agresif dan melanggar hukum serta melakukan kekerasan. Dengan demikian anggota Satpol PP dengan tingkat kecerdasan emosional yang baik, akan mampu melaksanakan tugasnya sesuai dengan perintah dan aturan yang ada. Meskipun dalam prosesnya harus berhadapan dengan situasi dan lingkungan yang kurang nyaman dan kondusifyang timbul saat proses penertiban.

Berdasarkan uji Analysis of Covariance (ANCOVA) dapat disimpulkan bahwa ada perbedaan tingkat agresivitas yang dimiliki oleh petugas Satpol PP ditinjau dari dimensi kepribadian big five (neuroticsm, extraversion, openness to experience, agreeableness, dan conscientiousness) dan kecerdasan emosional. Hasil penelitian juga menunjukkan bahwa kelompok subjek dengan dimensi kepribadian neuroticism memiliki rata-rata tingkat agresivitas yang lebih tinggi dibanding kelompok subjek lainnya, sedangkan kelompok subjek dengan rata-rata tingkat agresivitas yang paling rendah dimiliki oleh kelompok subjek dengan dimensi kepribadian openness to experience. Kontribusi kepribadian big five (neuroticsm, extraversion, openness to experience, agreeableness, dan conscientiousness) dan kecerdasan emosional terhadap tingkat agresivitas menunjukkan angka sebesar 0.365 yang berarti bahwa variabel kepribadian big five dan kecerdasan emosional dapat menjelaskan tingkat agresivitas hanya sebesar $36,5 \%$.

Adapun saran yang dapat peneliti berikan bagi peneliti selanjutnya yang tertarik untuk melakukan penelitian serupa disarankan agar dapat mempertimbangkan variabel-variabel lain yang dapat mempengaruhi tingkat agresivitas. Disarankan pula agar lebih memperhatikan aitem-aitem pernyataan yang terdapat pada skala pengukuran baik dari segi kualitas maupun kuantitasnya. Perlu adanya data tambahan seperti observasi dan wawancara sebagai tambahan acuan dalam menganalisis data agar hasil yang didapat lebih mendalam. Pada peneliti selanjutnya yang ingin melakukan penelitian serupa diharapkan tidak hanya berfokus pada Satpol PP saja, tetapi dapat melihat sampel lain. Bagi peneliti yang tertarik untuk melakukan penelitian yang serupa, terutama yang tertarik untuk meneliti Satpol PP diharapkan untuk dapat membangun kedekatan dengan melakukan komunikasi yang intens sehingga dapat menggali informasi yang lebih mendalam. Disarankan pula bagi peneliti selanjutnya untuk dapat mendapingi langsung saat proses pengisian kuisioner sehingga tidak terjadi keraguan dalam prosesnya. Untuk Instansi Satpol PP itu sendiri diharapkan dengan adanya penelitian ini dapat menjadi masukan serta bahan pertimbangan bagi instansi 
Satpol PP, sehingga dapat lebih memperhatikan anggota maupun calon anggotanya dari sisi kepribadian maupun kemampuan diri dalam menghadapi situasi-situasi kritis terkait dengan pengaruhnya terhadap tingkat agresivitas.

\section{DAFTAR PUSTAKA}

Anderson, \& Bushman. (2002). Human Aggression. Iowa State University.

Arikunto, S. (2002). Prosedur Penelitian Suatu Pendekatan Praktek (Edisi Revisi V). Yogyakarta: Rineka Cipta.

Aronson, Elliot. (2007). Social Psychology.Sixth edition. Pearson Educational, Inc., New Jersey.

Atkinson, R. (1997). Pengantar Psikologi. Jilid II. Jakarta: Erlangga.

Azwar, S. (1998). Metodologi Penelitian. Yogyakarta: Pustaka Pelajar.

Azwar, S. (2008).Penyusunan Skala Psikologi. Yogyakarta: Pustaka Pelajar.

Baron, R. A., \& Bryne, D. (2005). Psikologi sosial Jilid 2. Jakarta: Erlangga.

Bar -on, R. (2006). The Bar-On Model of Emotional-Social Intelligence (ESI).Psicothema 2006. Vol. 18, supl., pp. 1325.

Berkowitz, Leonard. (2005). Agresi: sebab \& akibatnya. Jakarta: PT Pustaka Binaman Pressindo.

Burger, Jerry M. (2008). Personality.Seventh edition.USA : Wadsworth, Cengage Learning.

Buss,\& Perry. (1992). The aggression questionnaire. Journal of Personality and Social Psychology Vol. 63 hal.452-458.

Travis, C., \& Wade, C. (2007). Psikologi. Jakarta: Erlangga.

Cooper,\& Sawaf. (1999). Executive EQ: Kecerdasan Emotional Dalam Kepemimpinan dan Organisasi (terjemahan Widodo). Jakarta: PT. Gramedia Pustaka Utama.

Costa,P.T.,\& McCrae, R.R. (1992). NEO PI-R Professional manual.Odesa, FL: Psychological Assesment Resources.

Dayaksini, T. H. (2009). Psikologi Sosial.Malang : UMM-Press.

Denson, T. F., Pedersen, W. C., \& Miller, N. (2006). The Displaced Aggression Questionnaire. Journal of Personality \& Social Psychology, Vol. 90 No 6 hal. 1032.

Engler, B. (2009). Personality theories. USA: Houghton Mifflin Harcourt Publishing Company.

Farida, Umi. (2007). Hubungan Tipe Kepribadian Ekstrovert dan Introvert dengan Perilaku Agresif pada Remaja. Malang: Universitas Islam Negeri Malang.

Farikha, Rikha. (2011). Pengaruh Tipe Kepribadian Big Five dan Kecerdasan Emosional Terhadap Perilaku Prososial Anggota Satuan Polisi Pamong Praja Kota Tanggerang. Jakarta: Universitas Islam Negeri Syarif Hidayatullah.

Fauziah, Syifa. (2014). Pengaruh Trait Kepribadian Big Five dan Konformitas Teman Sebaya terhadapAgresivitas Anak Punk di Jabodetabek. Jakarta: Universitas Islam Negeri Syarif Hidayatullah.

Fefriawati, Rita. (2010). Hubungan Antara Kecerdasan Emosional Dengan Perilaku Agresif Remaja Di SMKN 5 Padang. Padang: Universitas Andalas.

Feist, J., \& Feist, G. J. (2009). Theory of personality. New York: McGraw-Hill.

Firman.(2016) Manuasia Sebagai Makhluk Sosial.Diakses pada $\begin{array}{llll}\text { tanggal } & 4 & \text { November } & 2016 \quad \mathrm{di}\end{array}$ https://freemanof.wordpress.com/tugas/manusia_sebagai_m akhluk sosial/.

Friedman,\& Schustack. (2008). Kepribadian : Teori Klasik dan riset modern edisi ketiga jilid 1. Jakarta: Erlangga.

Ghufron, N. M.,\& Risnawati.(2010). Teori - Teori Psikologi.Yogyakarta: Ar-Ruzz Media.
Goleman, D. (2002). Kecerdasan emosional : Mengapa EI lebih penting daripada IQ. Terjemahan: Hermaya, T. Jakarta: Gramedia Pustaka Utama.

Goleman, D. (2002). Working With Emotional Intelligence (terjemahan). Jakarta: Gramedia Pustaka Utama.

Hadi, Sutrisno. (1991). Statistik Jilid II. Yogyakarta: Andi Offset.

Hair, J. F., Black, W. C., Babin, B. J., Anderson, R. E., \& Tatham, R. L. (2006). Multivariate Data Analisys, 6 Ed. New Jersey: Prentice Hall.

Indrariyani, W. (2013).Hubungan antara Kecerdasan Emosional dan Self Efficacydalam Pemecahan Masalah Penyesuaian Diri Remaja Awal.(Skripsi tidak dipublikasikan).Fakultas Kedokteran UNUD, Denpasar.

John, O. P. (1990). The "Big Five" factor taxonomy: Dimensions of personality in the natural language and in questionnaires. In L. A. Pervin (Ed.), Handbook of Personality: Theory and research (pp.66-100). New York: Guilford Press.

John, O. P., \& Soto, C. J. (2007).The importance of being valid: Reliability and the process of construct validation. In R. W. Robins, R. C. Fraley, \& R. F. Krueger (Eds.), Handbook of research methods in personality psychology (pp. 461-494). New York, NY: Cambridge University Press.

Kalat, James W. (2005). Introduction to Psychology.Seventh edition. USA: Wadsworth, Thomson Learning.

Khairani, A.,\& Nauly, M. (2011).Peran Kontrol Diri, Harga Diri, dan Gaya Atribusi Bermusuhan Terhadap Perilaku Agresif Satpol PP. Sumatera Utara: Universitas Sumatera Utara.

Koeswara, E. (1988). Agresi Manusia. Bandung: PT Eresco.

Krahe, Barbara. (2005). Perilaku agresif, buku panduan psikologi sosial. Yogyakarta: Pustaka Pelajar.

Luthfi, I., Saloom,G., \& Yasun, H., (2009). Psikologi Sosial.Jakarta: Lembaga Penelitian UIN Jakarta.

Mandasari, Etika. (2012). Sejarah Teori Big Five.Diakses pada tanggal $28 \quad$ April $2013 \quad \mathrm{di}$ http://11014ems.blogspot.com/2012/07/1-sejarah-teori-bigfive.html.

Martin, D. A. (2003).Emotional Quality Management, refleksi, revisi, dan revitalisasi hidup melalui kekuatan emosi. Ary Ginanjar Agustian (terjemahan). Jakarta: Arga.

Masruroh, R. (2007). Hubungan Antara Konsep Diri Dengan Penerimaan Teman Sebaya Pada Remaja Kelas XI MAN Malang I. Malang: Universitas Islam negeri Malang.

Mastur. (2012). Hubungan antara Tipe Kepribadian, Agresivitas dan Kontrol Diri pada Petarung Peresean. Yogyakarta: Universitas Gadjah Mada Yogyakarta.

Matlin, M.W. (1999). Psychology(3rd ed.). Texas: Harcourt Brace College Publishers.

McCrae, \& John. (Tanpa Tahun). An introduction to the five factor model \&it's application.

Moskat, H.J., \& Sorensen, K. M. (2012).Let's talk about feelings : Emotional Intelligence and Aggression Predict Juvenile Offense. Honors in Psychology, Whitman College.

Mukarromah, E. (2008). Hubungan antara Kecerdasan Emosional (Emotional Intelligence) dengan Perilaku Agresif pada Polisi Samapta di Polda Metro Jaya.Jakarta: Universitas Esa Unggul. Jurnal Psikologi Vol 6, No 1, Juni 2008.

Myers, David G. (2009). exploring social psychology_5th ed.USA: McGraw-Hill, Inc

Nugroho, A. (2005). Strategi Jitu memilih Metode statistic Penelitian dengan SPSS. Yogyakarta : Andi .

Nur, I. F., \& Ekasari, A. (2008). Hubungan antara Konsep Diri dengan Kecerdasan Emosional pada Remaja. Jurnal Soul, Vol. 1, No. 2, September 2008 .

Patton, P. (2000). EQ: pengembangan sukses lebih bermakna. Jakarta: Media Publishers.

Pervin, Lawrence, et al. (2005). personality theory \& research 9th ed.USA: John Willey \& Sons, Inc. 
Prasasti, R. A. N. (2011), Hubungan antara Dimensi Kepribadian Big Five dengan Perilaku Merokok pada Remaja Akhir. Jakarta: Universitas Islam Negeri Syarif Hidayatullah Jakarta.

Prasetyoaji, A (2012), Hubungan Kecerdasan Emosi dan Kecerdasan Spiritual dengan Perilaku Prososial Guru Bimbingan dan Konseling di Kabupaten Pacitan, Yogyakarta : Universitas Negeri Yogyakarta.

Pratama, A. Y. (2010). Hubungan antara Kecerdasan Emosi dengan Agresivitas Remaja Awal Pendukung Persija ( The Jakmania). Jakarta: Universitas Negeri Syarif Hidayatullah.

Pribadi, R. D. (2009). Hubungan atara Kecerdasan Emosi dengan Perilaku Agresif pada Anak Jalanan. Yogyakarta: Universitas Islam Indonesia.

Primaldhi, A. I. (tanpa tahun). Hubungan Antara Trait Kepribadian Neuroticism, Strategi Coping, dan Stres Kerja : Universitas Mercu Buana.

Priyatno, D. (2008). Mandiri Belajar SPSS: Untuk Analisis Data dan Uji Statistik. Jogjakarta: MediaKom.

Rahmatillah, Al-jum'atu.(2011). Pengaruh Tipe Kepribadian Big Five dan Self-Control Terhadap Agresivitas Satuan Polisi Pamong Praja Kota Tanggerang. Jakarta: Universitas Islam Negeri Syarif Hidayatullah.

Ramdhani, N. (2012). Adaptasi Bahasa dan Budaya Inventori Big Five.Yogyakarta: Universitas Gadjah Mada. Jurnal Psikologi Volume 39, No. 2, Desember 2012: 189 - 207.

Rudhanto, Wahyu. (2010). Satpol PP dan Otonomi Daerah.Diakses pada tanggal 4 Desember 2016 di Hhtp://wahyurudhanto.blogspot.co.id/2010/09/satpol-ppdan-otonomi-daerah.html?m=1.

Santoso, Singgih. (2005). Metode Penelitian Kuantitatif:Plus Aplikasi Program SPSS. Jakarta: PT Elex Media Komputindo.

Saptoto, R. (2010). Hubungan Kecerdasan Emosi dengan Kemampuan Coping Adaptif. Yogyakarta: Universitas Gadjah Mada. Jurnal Psikologi Vol 31, No 1, Juni 2010.

Sarwono, S. W. (2002). Psikologi Sosial.Individu dan Teori-Teori Psikologi Sosial. Jakarta: Balai Pustaka.

Setyani, U. (2007). Hubungan Antara Konsep Diri Dengan Intensi Menyontek Pada Siswa SMA NEGERI 2 Semarang. Semarang: Universitas Diponegoro.

Shaifa, D.(2013). Hubungan Dimensi Kepribadian The Big Five Personality dengan Penyesuaian Diri Mahasiswa Asing di Universitas Udayana. (Skripsi tidak dipublikasikan). Fakultas Kedokteran UNUD, Denpasar.

Shapiro, E. L. (2001). Mengajarkan Emotional Intelligence Pada Anak. Jakarta: Gramedia Pustaka Utama.

Siregar, S. (2013).Metode Penelitian Kuantitatif. Jakarta: Kencana Prenadamedia Group.

Sobur, A. (2003). Psikologi Umum. Bandung: Pustaka Setia.

Sugiyono. (2008). Metode Penelitian Kuantitatif, Kualitatif dan R \& D. Bandung: Penerbit Alfabeta.

Sugiyono. (2011). Statistika untuk Penelitian. Bandung: Alfabeta.

Sujanto, A., Lubis, H., \& Hadi, T. (2008).Psikologi Kepribadian. Jakarta: Bumi Aksara.

Suryabrata, S. (2000).Metodelogi Penelitian. Jakarta: PT Raja Grafindo Persada.

Suryabrata, S. (2008).Psikologi Kepribadian. Jakarta: PT Raja Grafindo Persada.

Taylor, S. E., Peplau, L. A., \& Sears, D. O. (2009).Psikologi Sosial.Jakarta: Kencana

Tremblay, P. F., (2002). A review of driver aggression research: conceptual, theoretical, and methodological issues. London, Ontario, Canada.

Weisinger, Hendrie. (2006). Emotional intelegence at work, Pemandu pikiran dan perilaku anda untuk meraih kesuksesan. Roro Ratih Ambarwati (terjemahan). Jakarta: PT Bhuana Ilmu Populer.
Widiyanti, Anis. (2012), Perilaku Agresif Taruna Akpol Ditinjau dari Kecerdasan Emosional dan Kontrol Diri. Semarang: Universitas Katolik Soegijapranata.

Widyarini, N. (2009). Relasi Orang Tua \& Anak. Yogyakarta: Elex Media Komputindo.

Wigins,\& Zanden. (1994). Social psychology_5th ed.USA:McGrawHill,Inc.

Yuliantari, W. (2015).Perbedaan Tingkat Kecemasan Siswa Kelas III SMA di Denpasar Ditinjau dari Efikasi Diri dan Keikutsertaan dalam Bimbingan Belajar Menjelang Ujian Nasional.(Skripsi tidak dipublikasikan). Fakultas Kedokteran UNUD, Denpasar.

Yusof, N.M.,\& Yaacob, N.R.N. (2012).Emotional Intelligence and Attitude of Students from Public Institutes of Higher Learning. Science Journal of Psychology. 
PERBEDAAN TINGKAT AGRESIVITAS

\section{LAMPIRAN}

Tabel 1

Hasil Uji Normalitas Data Agresivitas dan Kecerdasan Emosional ( $\mathrm{n}=135)$

\begin{tabular}{|cccl|}
\hline Skala & Kolmogorov-Smirnov & $\mathbf{p}$ & Kesimpulan \\
\hline Agresivitas & 1.164 & 0.133 & Data normal \\
Kecerdasan Emosional & 1.135 & 0.152 & Data normal \\
\hline
\end{tabular}


P. T. PRATIWI \& L. K. P. ARY

Tabel 2

Hasil Uji Homogenitas $(\mathrm{n}=135)$

\begin{tabular}{|cccc|}
\hline Skala & Levene Statistic & Sig. & Kesimpulan \\
\hline Agresivitas & 1.246 & 0.295 & Data Homogen \\
Kecerdasan Emosional & 1.578 & 0.184 & Data Homogen \\
\hline
\end{tabular}


Tabel 3

Hasil Uji Linearitas $(n=135)$

\begin{tabular}{|ccc|}
\hline Skala & Sig. & Kesimpulan \\
\hline Agresivitas * Kecerdasan Emosional & 0,000 & Data Linier \\
\hline
\end{tabular}


Tabel 4

Kategorisasi Skor Agresivitas

\begin{tabular}{ccccc|}
\hline Variabel & Rentang Nilai & Kategori Skor & Frekuensi & Persentase \\
\hline \multirow{4}{*}{ Agresivitas } & $\mathrm{x} \leq 57,75$ & Sangat Rendah & 9 & $6.7 \%$ \\
& $57,75<\mathrm{x} \leq 74,25$ & Rendah & 108 & $80 \%$ \\
& $74,25<\mathrm{x} \leq 90,75$ & Sedang & 18 & $13.3 \%$ \\
& $90,75<\mathrm{x} \leq 107,25$ & Tinggi & 0 & $0 \%$ \\
& $107,25<\mathrm{x}$ & Sangat Tinggi & 0 & $0 \%$ \\
\hline & Jumlah & & 135 & $100 \%$ \\
\hline
\end{tabular}


Tabel 5

Kategorisasi Skor Kecerdasan Emosional

\begin{tabular}{ccccc|}
\hline Variabel & Rentang Nilai & Kategori Skor & Frekuensi & Persentase \\
& $\mathrm{x} \leq 63$ & Sangat Rendah & 0 & $0 \%$ \\
Kecerdasan & $63<\mathrm{x} \leq 81$ & Rendah & 0 & $0 \%$ \\
Emosional & $81<\mathrm{x} \leq 99$ & Sedang & 13 & $9.6 \%$ \\
& $99<\mathrm{x} \leq 117$ & Tinggi & 99 & $73.3 \%$ \\
& $117<\mathrm{x}$ & Sangat Tinggi & 23 & $17 \%$ \\
\hline & Jumlah & & 135 & $100 \%$ \\
\hline
\end{tabular}


P. T. PRATIWI \& L. K. P. ARY

Tabel 6

Kriteria Kategorisasi Kepribadian Big Five

\begin{tabular}{|c|ccccc|}
\hline Kategorisasi & \multicolumn{5}{|c|}{ Kriteria Kategorisasi } \\
\cline { 2 - 5 } & Neuroticism & Extraversion & Openness to experience & Agreeableness & Conscientiousness \\
\hline Neuroticism & $\geq \mathbf{1 , 2 5}$ & $<0$ & $<0$ & $<0$ & $<0$ \\
Extraversion & $<0$ & $\geq \mathbf{1 , 2 5}$ & $<0$ & $<0$ & $<0$ \\
Openness to experience & $<0$ & $<0$ & $\geq \mathbf{1 , 2 5}$ & $<0$ & $<0$ \\
Agreeableness & $<0$ & $<0$ & $<0$ & $<\mathbf{1 , 2 5}$ & $<0$ \\
Conscientiousness & $<0$ & $<0$ & $<0$ & $<0$ & $\geq \mathbf{1 , 2 5}$ \\
\hline
\end{tabular}


Tabel 7

Kategorisasi Kepribadian Big Five

\begin{tabular}{ccc|}
\hline Kepribadian Big Five & Jumlah Subjek & Persentase \\
\hline Neuroticism & 27 & $20 \%$ \\
Extraversion & 27 & $20 \%$ \\
Openness to experience & 27 & $20 \%$ \\
Agreeableness & 27 & $20 \%$ \\
Conscientiousness & 27 & $20 \%$ \\
\hline Total & $\mathbf{1 3 5}$ & $\mathbf{1 0 0 . 0}$ \\
\hline
\end{tabular}


Tabel 8

Perhitungan Statistik Ancova $(\mathrm{n}=135)$

Dependent Variable:Agresivitas

\begin{tabular}{|ccccc|}
\hline $\mathrm{F}$ & $\mathrm{df1}$ & $\mathrm{df2}$ & Sig. \\
1.082 & 4 & & 130 & .368 \\
\hline
\end{tabular}

Tests the null hypothesis that the error variance of the dependent variable is equal across groups.

a. Design: Intercept + Kecerdasan + Kepribadian 
PERBEDAAN TINGKAT AGRESIVITAS

Tabel 9

Perhitungan Statistik Ancova $(\mathrm{n}=135)$

Tests of Between-Subjects Effects

Dependent Variable:Agresivitas

\begin{tabular}{|cccccc|}
\hline & $\begin{array}{c}\text { Type III Sum of } \\
\text { Squares }\end{array}$ & df & Mean Square & F & Sig. \\
\hline Corrected Model & $2527.279^{\mathrm{a}}$ & 5 & 505.456 & 16.401 & .000 \\
Intercept & 6466.355 & 1 & 6466.355 & 209.817 & .000 \\
Kecerdasan & 1164.938 & 1 & 1164.938 & 37.799 & .000 \\
Kepribadian & 450.219 & 4 & 112.555 & 3.652 & .007 \\
Error & 3975.654 & 129 & 30.819 & & \\
Total & 602111.000 & 135 & & & \\
Corrected Total & 6502.933 & 134 & & & \\
\hline
\end{tabular}

a. R Squared $=, 389$ (Adjusted $R$ Squared $=, 365$ ) 
Tabel 10

Perhitungan Statistik Anova $(\mathrm{n}=135)$

Tests of Between-Subjects Effects

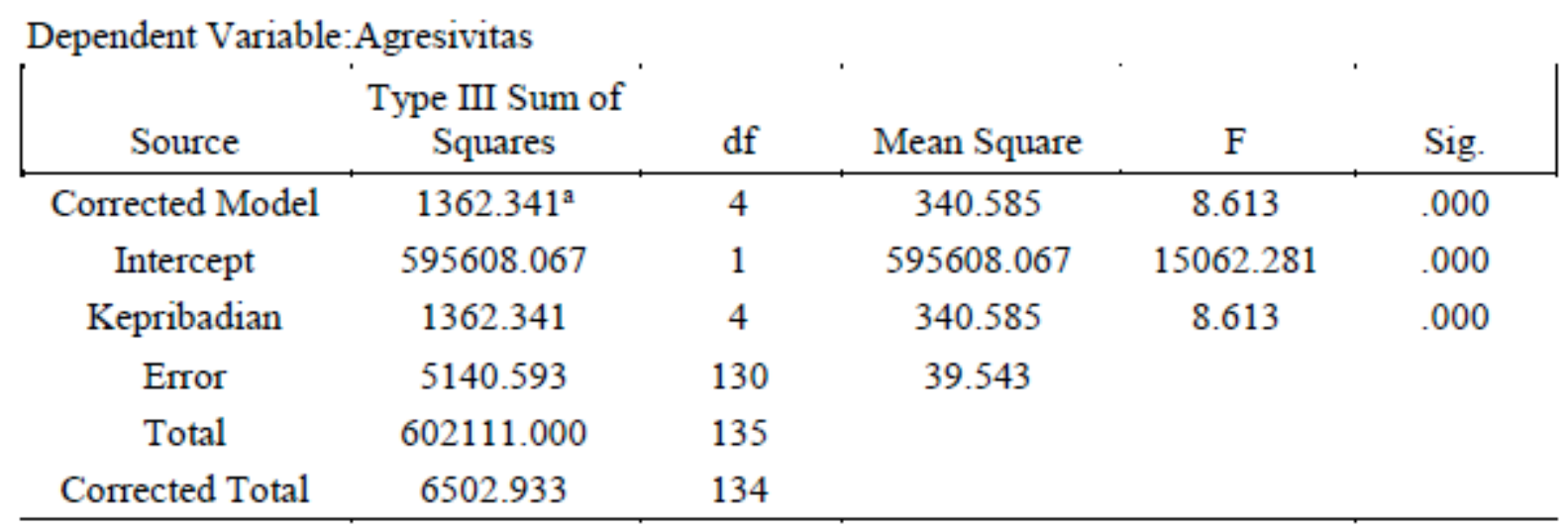

a. $\quad$ R Squared $=, 209$ (Adjusted R Squared $=, 185$ ) 


\section{Tabel 11}

Mean, Standar Deviasi Kelompok Dimensi Kepribadian Big Five ( $\mathrm{n}=135)$

\section{Descriptive Statistics}

Dependent Variable:Agresivitas

\begin{tabular}{cccc|}
\hline Big Five & Mean & Std. Deviation & N \\
\hline Neuroticism & 72.59 & 6.338 & 27 \\
Extraversion & 65.33 & 7.136 & 27 \\
Openness & 63.52 & 4.910 & 27 \\
Agreeableness & 65.78 & 7.366 & 27 \\
Conscientiousness & 64.89 & 5.316 & 27 \\
\hline Total & 66.42 & 6.966 & 135 \\
\hline
\end{tabular}


P. T. PRATIWI \& L. K. P. ARY

Tabel 12

Estimated Marginal Means Dimensi Kepribadian Big Five $(\mathrm{n}=135)($ dengan adanya kovariat $)$

\section{Big Five}

\begin{tabular}{ccccc|}
$\begin{array}{c}\text { Dependent Variable:Agresivitas } \\
\text { Big Five }\end{array}$ & Mean & Std. Error & Lower Bound & Upper Bound \\
\hline Neuroticism & $69.657^{\mathrm{a}}$ & 1.170 & 67.342 & 71.973 \\
Extraversion & $66.480^{\mathrm{a}}$ & 1.085 & 64.334 & 68.626 \\
Openness & $63.806^{\mathrm{a}}$ & 1.069 & 61.690 & 65.922 \\
Agreeableness & $65.487^{\mathrm{a}}$ & 1.069 & 63.371 & 67.603 \\
Conscientiousness & $66.680^{\mathrm{a}}$ & 1.107 & 64.489 & 68.871 \\
\hline
\end{tabular}

a. Covariates appearing in the model are evaluated at the following values: Kecerdasan Emosional $=109,43$. 
Tabel 13

Rangkuman Hasil Uji Hipotesis Penelitian

\begin{tabular}{|c|c|c|c|}
\hline No & & Hipotesis & Hasil \\
\hline 1 & Ho & $\begin{array}{l}\text { Tidak ada perbedaan tingkat agresivitas petugas Satuan Polisi Pamong Praja } \\
\text { ditinjau dari dimensi kepribadian big five (neuroticsm, extraversion, openness to } \\
\text { experience, agreeableness, dan conscientiousness) dan kecerdasan emosional }\end{array}$ & Ditolak \\
\hline 2 & На & $\begin{array}{l}\text { Ada perbedaan tingkat agresivitas petugas Satuan Polisi Pamong Praja ditinjau } \\
\text { dari dimensi kepribadian big five (neuroticsm, extraversion, openness to } \\
\text { experience, agreeableness, dan conscientiousness) dan kecerdasan emosional. }\end{array}$ & Diterima \\
\hline
\end{tabular}

